\title{
In vitro antimicrobial activity of total extracts of the leaves of Petiveria alliacea L. (Anamu)
}

\author{
Ania Ochoa Pacheco ${ }^{1 *}$, Jorge Marín Morán', Zenia González Giro², Adrian Hidalgo Rodríguez, \\ Rachel Juliet Mujawimana ${ }^{1}$, Karel Tamayo González ${ }^{1}$, Sandra Sariego Frómeta ${ }^{3}$
}

\author{
${ }^{1}$ Department of Pharmacy, Faculty of Natural Sciences, University of Oriente, Santiago de Cuba, Cuba, ${ }^{2}$ Center for Industrial \\ Biotechnology Studies, Faculty of Natural Sciences, University of Oriente, Santiago de Cuba, Cuba, ${ }^{3}$ Center for Plant \\ Biotechnology, University of Granma, Bayamo, Granma, Cuba
}

\begin{abstract}
The antimicrobial activity of 13 total extracts was evaluated, 10 soft extracts (B) and 3 blended extracts (E) prepared from dry and fresh leaves of Petiveria alliacea L. Various solvents were used for their preparation: hydroalcoholic solution at $30 \%, 80 \%$ and isopropyl alcohol. The antimicrobial effect of the extracts was tested by means of the method of Kirby-Bauer, using four bacterial strains from the ATCC collection (Escherichia coli, Staphylococcus aureus, Enterococcus faecalis and Pseudomonas aeruginosa) and a leveduriform fungus (Candida albicans). The following quality control parameters were determined for most active extracts: physical, physical-chemical and chemical parameters. The results were: nine extracts showed antibacterial activity, being the most concentrated (B8 and E3), the ones with the highest activity in the presence of the bacteria tested; the effect of blended extracts (E1, E2 and E3) was greater in the presence of $P$. aeruginosa. Blended extracts are considered more potent and active than soft extracts. No antifungal activity was obtained for both types of extracts. The Minimum Inhibitory Concentration (MIC) and Minimum Bactericidal Concentration (MBC) were determined for both extracts, with the following results: MIC-soft extracts $(>100 \mathrm{mg} / \mathrm{mL})$, blended extracts $(>50 \mathrm{mg} /$ $\mathrm{mL})$; MBC-soft extracts $(\geq 400 \mathrm{mg} / \mathrm{mL})$, blended extracts $(\geq 200 \mathrm{mg} / \mathrm{mL})$ based on fresh leaves.
\end{abstract}

Key words: Antimicrobial activity. Anamu. Soft extracts. Blended extracts. Minimum Inhibitory Concentration.

\begin{abstract}
Avaliou-se a atividade antimicrobiana de 13 extratos totais, 10 brandos (B) e 3 batidos (E) elaborados a partir da folha seca e fresca da Petiveria alliacea L. Para sua preparação se empregaram vários solventes: solução hidroalcoólica $30 \%, 80 \%$ e álcool isopropílico. O efeito antimicrobiano dos extratos foi comprovado pelo método do Kirby-Bauer, usando para isso quatro cepas bacterianas da coleção ATCC (Escherichia coli, Staphylococcus aureus, Enterococcus faecalis e Pseudomonas aeruginosa) e um fungo leveduriforme (Candida albicans). Determinaram-se parâmetros de controle da qualidade físicos, físico-químicos e químicos dos extratos mais ativos. Obtiveram-se como resultados: que 9 extratos mostraram atividade antibacteriana, sendo os mais concentrados (B8 e E3) os de maior espectro de ação frente às bactérias provadas; o efeito dos extratos batidos (E1, E2 e E3) foi maior frente a $P$. aeruginosa; os extratos batidos se consideram mais ativos que os brandos e não se obteve atividade antifúngica caso algum. Determinou-se a Concentração Mínima Inhibitoria e Bactericida para ambos os extratos, resultando a primeira para os extratos brandos maior a $100 \mathrm{mg} / \mathrm{mL}$ e para as batidos maior a $50 \mathrm{mg} / \mathrm{mL}$; a segunda para os extratos brandos maior ou igual a $400 \mathrm{mg} / \mathrm{mL}$ e para as batidos maior ou igual a $200 \mathrm{mg} / \mathrm{mL}$, em relação à droga fresca.
\end{abstract}

Unitermos: Atividade antimicrobiana. Anamú. Extratos brandos. Extratos batidos. Concentração mínima inibitória.

\footnotetext{
*Corresponding author: A. O. Pacheco. Department of Pharmacy, Faculty of Natural Sciences, University of Oriente. Home address: Pizarro No. 24, entre Trocha y Primera, Reparto Flores. Santiago de Cuba 3, CP 9030 - Santiago de Cuba, Cuba. E-mail: aochoa@cnt.uo.edu.cu; anianay15@yahoo.com.br
} 


\section{INTRODUCTION}

Anamu (Petiveria alliacea L.), is a plant from the family Phytolaccaceae, known by different names in different countries of Central and South America, the Caribbean and Africa. It is described as a tall straight perennial herb, slightly branched and is 0.5 to $1 \mathrm{~m}$ tall, with alternate leaves in elliptic form and 6 to $19 \mathrm{~cm}$ long and up to $5 \mathrm{~cm}$ wide. Its flowers are small and white; the fruit is a cuneiform berry that has four hooks turned downwards. Its use as a medicinal plant dates back to pre-Columbian times according to references that show its use by the Mayas (Illnait, 2007).

This plant species has been studied by researchers of the Department of Pharmacy of the University of Oriente (Ochoa, Pupo, Duany, 2000; Ochoa et al., 2006a,b; Ochoa et al., 2008a,b); complying with the Critical Route of Investigation of medicinal plants established by the Center for Quality Control of Medicines of Cuba (CECMED, 1997); achieving the elaboration of an antiinflammatory herbal medicine to treat Psoriasis. During these investigations, it was observed that herbal extracts studied as active ingredients of this medicine used to treat psoriasis do not undergo any antimicrobial contamination when exposed to uncontrolled conditions of storage.

For this reason, and taking into account various aspects, such as:

- that in bibliography revisions (Seokwon, Roman, Rabi, 2006; Lemus et al., 2004; Caceres, López, González, 1998; Lapenna et al., 2003; Guedes et al., 2009; Benevides et al., 2001) works indicating antimicrobial activity of certain alcoholic extracts from leaves and roots have been found;

- $\quad$ in some of these revisions (Seokwon, Roman, Rabi, 2006) is cited that, the drying temperature has a negative influence on the antimicrobial chemical composition;

- $\quad$ that the metabolites (Seokwon, Roman, Rabi, 2006), responsible for the antimicrobial activity have an apolar nature;

- $\quad$ and also the increasing need to search for antimicrobial medicines due to the increase of bacterial resistance;

We decided to evaluate the antimicrobial activity of 10 soft extracts and three blended extracts from Petiveria alliacea L. using the Kirby-Bauer Disk Diffusion Method. We also determine the Minimum Inhibitory and Bactericidal Concentration and quality control parameters like physical, physical-chemical and qualitative chemical parameters of most active extracts; verifying the influence of drying temperature on the chemical composition responsible for antimicrobial activity, as well as the apolar nature of such constituents.

If the antimicrobial activity of these total extracts is confirmed, then the pharmaceutical industry will have new active pharmaceutical ingredients (APIs) for the possible design, preparation and therapeutic utilization of herbal medicines as alternative therapies that respond to current health problems and those related to antimicrobial use.

\section{MATERIAL AND METHODS}

The leaves of Petiveria alliacea L. were collected in the city of Santiago de Cuba, Cuba, in January 2011 and were identified by Félix Acosta Cantillo, PhD. A sample is deposited in the Herbarium of the Eastern Center of Ecosystems and Biodiversity (BIOECO, Spanish acronym), attached to the Academy of Sciences of Cuba; under voucher specimen number 4383 .

\section{Preparation of extracts}

Extracts were prepared in the Pharmaceutical Technology Laboratory of the Department of Pharmacy of the University of Oriente and were the following: 10 Soft extracts

3 Blended extracts.

For soft extracts: according to the Public Health Standard 311 (NRSP 311, 1991), different proportions were obtained, both with dry and fresh drug, as well as with three different solvents, as follows:

B1: Proportion 1:4, with dry drug and hydroalcoholic solution at $30 \%$; B2: Proportion $1: 6$, with dry drug and hydroalcoholic solution at $30 \%$; B3: Proportion $1: 4$, with fresh drug and hydroalcoholic solution at $30 \%$; B4: Proportion 1:6, with fresh drug and hydroalcoholic solution at 30\%; B5: Proportion 1:4, with fresh drug and hydroalcoholic solution at 80\%; B6: Proportion 1:6, with fresh drug and hydroalcoholic solution at $80 \%$; B7: Proportion 1:8, with fresh drug and hydroalcoholic solution at $80 \%$; B8: Proportion 1:12, with fresh drug and hydroalcoholic solution at $80 \%$; B9: proportion 1:4, with fresh drug and isopropyl alcohol; B10: proportion 1:6, with fresh drug and isopropyl alcohol.

For blended extracts: three hundred grams (300 g) of fresh leaves were weighed and then blended using a Waring blender from the USA; small volumes of 94\% alcohol were added at regular intervals to facilitate the blending of the leaves until $300 \mathrm{~mL}$ of solvent had been used. Later, the extract was soaked for 48 hours and afterwards filtration was carried out in a vacuum 
obtaining an extract named E. We took certain volumes from the same extract to obtain three proportions by rotoevaporation at a temperature of $35^{\circ} \mathrm{C}$; and they were named accordingly:

E1 - Proportion 1:4, with fresh drug and hydroalcoholic solution at $80 \%$; E2 - Proportion 1:6, with fresh drug and hydroalcoholic solution at $80 \%$; E3 - Proportion $1: 8$, with fresh drug and hydroalcoholic solution at $80 \%$.

Leaves were dried in the sun until constant weight was obtained (Ochoa, Pupo, Duany, 2000).

Fluid extract was prepared using the percolation method, and each milliliter matches one gram of dry drug. From the same extract, various soft extracts were prepared, taking different volumes and concentrating them on rotoevaporator according to the different proportions used $(1: 4,1: 6,1: 8,1: 12)$.

\section{Determination of antimicrobial activity}

The study was done in the Laboratory of Microbiology of the Center for Industrial Biotechnology Studies (CEBI, Spanish acronym) at the University of Oriente. Strains of reference were used:

Staphylococcus aureus ATCC 29212

Escherichia coli ATCC 25922

Enterococcus faecalis ATCC 29212

Pseudomonas aeruginosa ATCC 27853

Candida albicans CCEBI 2048

Ciprofloxacin discs $(5 \mu \mathrm{g})$ from the Carlos J. Finlay Company of Biological Products were used as positive controls for the antibacterial activity and ketoconazole discs $(30 \mu \mathrm{g})$ for the antifungal activity, which were prepared at the CEBI. control.

Sterile distilled water was used as the negative

The Kirby-Bauer disk susceptibility method was used according to recommendations of the National Committee for Clinical Laboratory Standards (NCCLS, 2002).

Six-millimeter diameter disks (6 mm) obtained from Whatman filter paper were used, $10 \mu \mathrm{L}$ of each concentration of extracts to be tested were dispensed on disks as well as positive and negative controls.

Results obtained from the measurement of the inhibition zone diameters were analyzed based on the criteria for the interpretation of the in vitro susceptibility of microorganisms when exposed to the antimicrobial, comparing them with the patrons established by the NCCLS, categorizing the strains as sensitive (S), Intermediate (I) and Resistant (R).

An extract was considered active $(+)$ when the inhibition zone diameter was higher than $6 \mathrm{~mm}$ (Seokwon, Roman, Rabi, 2006).

\section{Determination of Minimum Inhibitory Concentration (MIC) and Minimum Bactericidal Concentration (MBC)}

The minimum concentration of the extract capable of in vitro inhibiting the visible growth of the microorganism (MIC) was determined. For the experiment, serial double dilutions were made according to the NCCLS standard (NCCLS, 2002). These dilutions were carried out for B5-8 and E1-3 extracts. The minimum concentration capable of lysing the $99.9 \%$ of the inoculum's cells (MBC) was found by means of the MIC

Diluted antimicrobial agents together with a standardized quantity of pure isolated organism were incubated for 18-24 hours and were observed until the bacterial growth developed. The minimum quantity of antimicrobial needed to inhibit growth is known as the MIC (Laboratory of Reference, 2007).

Tubes containing serial dilutions of the extracts were inoculated. The dilution experiment was carried out in a liquid medium recommended by NCCLS, 2002.

Preparation of the dilutions of the extract: Serial dilutions of the extracts were prepared.

Preparation of the inoculum for the strain used:

- A suspension of the microorganism being studied was taken, with turbidity comparable to the 0.5 McFarland scale (they were previously prepared for inoculation of antibiogram plates).

- A 1/100 dilution of said suspension was carried out in Mueller Hinton Medium (MHM) $(100 \mu \mathrm{L}$ in $9.9 \mathrm{~mL}$ of MHM).

\section{For the Control Strain:}

- A suspension of the control strain was taken, with turbidity comparable to the $0.5 \mathrm{McF}$ arland scale (they were previously prepared for inoculation of antibiogram plates);

- A 1/100 dilution of said suspension was carried out in $\mathrm{MHM}(100 \mu \mathrm{L}$ in $9.9 \mathrm{~mL}$ of $\mathrm{MHM})$.

\section{Culturing in tubes:}

- All tubes with dilutions of the extract were inoculated with $1 \mathrm{~mL}$ of the previously obtained inoculum using a pipette.

- A growth control (1 mL of MHM $+1 \mathrm{~mL}$ of inoculum) was included for each strain.

- Dilutions were incubated for $20 \mathrm{~h}$ at $37^{\circ} \mathrm{C}$ in a MLW incubator model BRUWA-8, from Germany. 


\section{Determination of physical, physical-chemical and chemical quality control parameters of active extracts}

Quality control parameters of most active extracts were determined:

Physical and Physical-chemical parameters (NRSP 312, 1991)

a - Organoleptic characteristics

$\mathrm{b}-\mathrm{pH}$

c - Relative density

d - Total solids

e - Refraction index

Qualitative chemistry parameter

f - Phytochemical screening (Ochoa, López, Colombat, 2002)

Chemical Parameter

$\mathrm{g}$ - Determination of total phenols: the Folin-Ciocalteu method was used. (Singleton, Rossi, 1965).

Preparation of the test sample

One milliliter $(1 \mathrm{~mL})$ of anamu extracts was taken and diluted in a $100 \mathrm{~mL}$ volumetric flask, and then it was leveled up and labeled. Later, the mixture was stored away from light.

\section{Preparation of the blank}

Five milliliters $(5 \mathrm{~mL})$ of distilled water were placed in a $25 \mathrm{~mL}$ volumetric flask and then $2 \mathrm{~mL}$ of reactive solution for tannins (Folin-Ciocalteu method) was added, it was then agitated moderately, and $1 \mathrm{~mL}$ of sodium carbonate solution was added to level it up with distilled water and homogenize it.

\section{Preparation of the sample to be measured}

The test sample solution was filtered using filter paper. Five milliliters $(5 \mathrm{~mL})$ were taken and added to a $25 \mathrm{~mL}$ volumetric flask. Two milliliters $(2 \mathrm{~mL})$ of the reactive solution were added, agitated using circular motion and then left to rest for 5 minutes. Then, $1 \mathrm{~mL}$ of sodium carbonate at $20 \%$ was added; it was leveled up, homogenized and then left to rest for 5 minutes to measure the absorbance of dissolutions prepared before in a spectrophotometer (ULTROSPEC 1000 from England) at $700 \mathrm{~nm}$.

\section{Processing and analyses of results}

The values of the different zones of inhibition of growth as well as the quality control results (total solid values and $\mathrm{pH}$ ) and total phenol values, were submitted to a statistical analysis using the STATGRAPHICS Plus version 5.1 software of the year 2001; then the T-student test and an analysis of variance of simple classification, with a test of multiple ranges (Tukey's HSD test (Honestly Significant Difference)) were performed to evaluate if sample means were equal or different.

Data comply with the standards of a parametric analysis and follow a normal distribution.

\section{RESULTS AND DISCUSSION}

\section{Processing of plant material}

The taxonomic identification performed to the plant species corroborated that we worked with Petiveria alliacea $\mathrm{L}$.

\section{Determination of antimicrobial activity}

Table I shows the results of the determination of antimicrobial activity for the 13 extracts.

From the analysis of Table I, the following observations were shown:

Extracts B1, B2, B3 and B4 do not show antimicrobial activity in the presence of microorganisms used. Extracts B5, B6, B7, B8, B9, B10, E1, E2 and E3 show antimicrobial activity in the presence of the tested bacteria.

Among soft extracts made with the hydroalcoholic solution at $80 \%$, the $\mathrm{B} 8$ resulted to be the most active in the presence of the four bacteria tested.

Among the soft extracts made with isopropyl alcohol, the B10 resulted to be the most active in the presence of $S$. aureus and E. coli.

Among the blended extracts with hydroalcoholic solution at $80 \%$, the $\mathrm{E} 3$ resulted to be the most active in the presence of the four bacteria tested.

$S$. aureus and $P$. aeruginosa bacteria were the most sensitive in the presence of the majority of the extracts evaluated ( $S$. aureus in nine extracts and $P$. aeruginosa in seven extracts).

Greater values of zones of inhibition of growth were obtained in the presence of $P$. aeruginosa with seven of the extracts evaluated, being higher in E2 and E3 extracts comparable with those reported by NCCLS for Ciprofloxacin in the intermediate range (14-17 mm).

In E1, E2 and E3 blended extracts, a greater concentration of antimicrobial substances could be extracted, such as: sulfur compounds described in the literature (Seokwon, Roman, Rabi, 2006), phenols and tannins (Escalona, 2005; González, Lechuga, Serrano, 
TABLE I - Determination of antimicrobial activity: Mean values of the inhibition zones for positive results

\begin{tabular}{|c|c|c|c|c|c|}
\hline $\begin{array}{l}\text { m.o } \\
\text { Sample }\end{array}$ & $\begin{array}{c}\text { S. aureus } \\
\text { (Mean } \pm \text { standard } \\
\text { error) }\end{array}$ & $\begin{array}{c}\text { E. coli } \\
\text { (Mean } \pm \text { standard } \\
\text { error ) }\end{array}$ & $\begin{array}{c}\text { E. faecalis } \\
\text { (Mean } \pm \text { standard } \\
\text { error ) }\end{array}$ & $\begin{array}{c}\text { P. aeruginosa } \\
\text { (Mean } \pm \text { standard } \\
\text { error) }\end{array}$ & C. albicans \\
\hline B1 & $(-)$ & $(-)$ & $(-)$ & $(-)$ & $(-)$ \\
\hline B2 & $(-)$ & $(-)$ & $(-)$ & $(-)$ & $(-)$ \\
\hline B3 & $(-)$ & $(-)$ & $(-)$ & $(-)$ & $(-)$ \\
\hline B4 & $(-)$ & $(-)$ & $(-)$ & $(-)$ & $(-)$ \\
\hline B5 & $\begin{array}{c}(+) \\
7.0 \pm 0.28^{\mathrm{a}}\end{array}$ & $(-)$ & $(-)$ & $\begin{array}{c}(+) \\
8.0 \pm 0.57^{c}\end{array}$ & $(-)$ \\
\hline B6 & $\begin{array}{c}(+) \\
7.5 \pm 0.28^{a}\end{array}$ & $\begin{array}{c}(+) \\
6.6 \pm 0.16^{\mathrm{e}}\end{array}$ & $(-)$ & $\begin{array}{c}(+) \\
7.66 \pm 0.33^{c}\end{array}$ & $(-)$ \\
\hline B7 & $\begin{array}{c}(+) \\
7.16 \pm 0.16^{\mathrm{a}}\end{array}$ & $(-)$ & $\begin{array}{c}(+) \\
7.16^{ \pm} 0.16^{\mathrm{h}}\end{array}$ & $\begin{array}{c}(+) \\
8.33 \pm 0.33^{c}\end{array}$ & $(-)$ \\
\hline B8 & $\begin{array}{c}(+) \\
7.5 \pm 0.28^{\mathrm{a}}\end{array}$ & $\begin{array}{c}(+) \\
7.16 \pm 0.16^{\mathrm{ef}}\end{array}$ & $\begin{array}{c}(+) \\
7.66 \pm 0.16^{\mathrm{h}}\end{array}$ & $\begin{array}{c}(+) \\
8.33 \pm 0.33^{c}\end{array}$ & $(-)$ \\
\hline B9 & $\begin{array}{c}(+) \\
7.33 \pm 0.16^{\mathrm{a}}\end{array}$ & $(-)$ & $(-)$ & $(-)$ & $(-)$ \\
\hline B10 & $\begin{array}{c}(+) \\
7.53 \pm 0.03^{\mathrm{ab}}\end{array}$ & $\begin{array}{c}(+) \\
6.73 \pm 0.14^{\mathrm{e}}\end{array}$ & $(-)$ & $(-)$ & $(-)$ \\
\hline E1 & $\begin{array}{c}(+) \\
7.66 \pm 0.33^{b}\end{array}$ & $(-)$ & $(-)$ & $\begin{array}{c}(+) \\
9.16 \pm 0.44^{d}\end{array}$ & $(-)$ \\
\hline E2 & $\begin{array}{c}(+) \\
8.5 \pm 0.28^{b}\end{array}$ & $(-)$ & $(-)$ & $\begin{array}{c}(+) \\
13.5 \pm 0.28^{d}\end{array}$ & $(-)$ \\
\hline E3 & $\begin{array}{c}(+) \\
8.5 \pm 0.5^{b}\end{array}$ & $\begin{array}{c}(+) \\
7.83 \pm 0.16^{f}\end{array}$ & $\begin{array}{c}(+) \\
7.5 \pm 0.28^{\mathrm{h}}\end{array}$ & $\begin{array}{c}(+) \\
14.0 \pm 0.28^{d}\end{array}$ & $(-)$ \\
\hline Ketoconazole & - & - & - & - & $\begin{array}{c}(+) \\
25.16\end{array}$ \\
\hline Ciprofloxacin & $\begin{array}{c}(+) \\
23.5\end{array}$ & $\begin{array}{c}(+) \\
28.33\end{array}$ & $\begin{array}{c}(+) \\
23.33\end{array}$ & $\begin{array}{c}(+) \\
25.66\end{array}$ & - \\
\hline Water & $(-)$ & $(-)$ & $(-)$ & $(-)$ & $(-)$ \\
\hline
\end{tabular}

Key:_(+): Active (-): Inactive m.o: microorganisms Mtra: Sample.

Different superindexes show a significant difference between the samples $(\mathrm{p}<0.05)$, in each bacteria.

2000); which is corroborated with the increase of the zones of inhibition of growth obtained; therefore, this method of extraction has higher extractive capacity, achieving a greater pharmacologic activity.

Under these working conditions, no activity was obtained for any of the extracts in the presence of $\mathrm{C}$. albicans, not coinciding with the information contained in the literature (Seokwon, Roman, Rabi, 2006; Berdy, Hostian, Nitt, 1982) in the case of Anamu leaves.

It was corroborated that the drying temperature influences the antimicrobial chemical composition (Seokwon, Roman, Rabi, 2006) since the extracts elaborated from the dry drug (B1 and B2) do not show any activity.
It was shown that the components responsible for the antimicrobial activity have an apolar nature, since, even tough the B3 and B4 extracts are prepared with the fresh drug, when the hydroalcoholic solution at $30 \%$ is used no positive results are obtained, but positive results are obtained when using the hydroalcoholic solution at $80 \%$ (a more apolar solution when compared with the solution at 30\%) (B5 and B6) and isopropyl alcohol (B9 and B10).

The following observation can be obtained from the statistical analysis (Annex 1): blended extracts showed significant statistical differences when compared with soft extracts, for a $95 \%$ of confidentiality for Staphylococcus aureus and Pseudomonas aeruginosa, whereby the activity of both extracts differed, being higher in blended extracts. 
Besides, in general terms, the antimicrobial activity does not show significant statistical differences among soft and blended extracts, as well as among blended extracts, in the presence of all bacteria tested. $((\mathrm{p}<0.05)$. (Table I).

Taking into account the criteria for the interpretation of in vitro susceptibility of microorganisms in the presence of extracts, the following comment was made:

Intermediate classification (NCCLS, 2002) for $P$. aeruginosa in the presence of 2 and $\mathrm{E} 3$ blended extracts, since inhibition zones of 13.5 and $14 \mathrm{~mm}$ were obtained respectively, taking into account the ciprofloxacin.

Criteria for the interpretation of in vitro susceptibility of microorganisms, according to NCCLS:

Ciprofloxacin $5 \mu \mathrm{g}$ :

$\geq 18 \mathrm{~mm} \rightarrow$ Susceptible; $14-17 \mathrm{~mm} \rightarrow$ Intermediate; $\leq 13 \mathrm{~mm} \rightarrow$ Resistant.

\section{Determination of minimum inhibitory concentration and minimum bactericidal concentration}

Thirty-five levels of concentration were analyzed. Results of this analysis are shown in Table II.

Taking into account these values, it can be considered that blended extracts present a higher antimicrobial activity, since their MIC and MBC show lowest values, showing therefore a greater activity than soft extracts.

Seokwon, Roman, Rabi (2006) refer to lower
TABLE II - MIC and the MBC for P. aeruginosa on the basis of fresh drugs

\begin{tabular}{lcc}
\hline Samples & MIC $(\mathrm{mg} / \mathrm{mL})$ & MBC $(\mathrm{mg} / \mathrm{mL})$ \\
\hline $\mathrm{B}_{5-6-7-8}$ & $>100$ & $\geq 400$ \\
$\mathrm{E}_{1-2-3}$ & $>50$ & $\geq 200$ \\
\hline
\end{tabular}

Key: $\mathrm{B}_{\text {5-6-7-8 } 8}:$ Soft Extracts tested. $\mathrm{E}_{1-2-3}:$ Blended Extracts Tested. Three replicas

MIC values $(0.512 \mathrm{mg} / \mathrm{mL})$ than those obtained in this study with synthetic compounds responsible for the antimicrobial action derived from the roots; however, it is valid to emphasize that our results were obtained from the leaf and total extracts, for this reason, they not only have compounds with antimicrobial activity (which are found in small concentrations in leaves: $0.08 \mathrm{mg} / \mathrm{g}$ ) but also other compounds; these aspects justify the values of MIC and MBC obtained under these working conditions and that can be of clinical interest in future researches.

\section{Determination of Physical, Physical-chemical and Chemical quality control parameters of active extracts}

Table III shows the results of the physical and physical-chemical quality control of B5-8 and E1-3 extracts.

TABLE III - Average results of the physical and physical-chemical quality control of some extracts

\begin{tabular}{|c|c|c|c|c|c|}
\hline Extracts & Organoleptic characteristics & $\begin{array}{c}\text { Total solids (St) } \\
\mathrm{g} / 100 \mathrm{~mL} \\
(\text { Mean } \pm \text { Standard error })\end{array}$ & $\begin{array}{l}\text { Relative } \\
\text { Density }\end{array}$ & $\begin{array}{c}\mathrm{pH} \\
\text { (Mean } \pm \text { Standard } \\
\text { error) }\end{array}$ & $\begin{array}{l}\text { Refraction } \\
\text { Index }\end{array}$ \\
\hline B5 & $\begin{array}{l}\text { Color: Dark Brown } \\
\text { Smell: Garlicky Homogeneity }\end{array}$ & $7.146 \pm 0.004^{\mathrm{a}}$ & 0.9749 & $6.44 \pm 0.01^{\mathrm{a}}$ & 1.3520 \\
\hline B6 & $\begin{array}{l}\text { Color: Dark Brown } \\
\text { Smell: Garlicky Homogeneity }\end{array}$ & $12.054 \pm 0.051^{\mathrm{b}}$ & 0.9966 & $6.4 \pm 0.15^{\mathrm{a}}$ & 1.3590 \\
\hline B7 & $\begin{array}{l}\text { Color: Dark Brown } \\
\text { Smell: Garlicky Homogeneity }\end{array}$ & $17.376 \pm 0.024^{\mathrm{c}}$ & 1.0303 & $6.38 \pm 0.15^{\mathrm{a}}$ & 1.3615 \\
\hline B8 & $\begin{array}{l}\text { Color: Dark Brown } \\
\text { Smell: Garlicky Homogeneity }\end{array}$ & $18.934 \pm 0.095^{\mathrm{d}}$ & 1.0583 & $6.32 \pm 0.02^{\mathrm{a}}$ & 1.3690 \\
\hline E1 & $\begin{array}{l}\text { Color: Dark Brown } \\
\text { Smell: Garlicky Homogeneity }\end{array}$ & $13.17 \pm 0.05^{\mathrm{e}}$ & 1.0405 & $6.01 \pm 0.02^{\mathrm{b}}$ & 1.3435 \\
\hline E2 & $\begin{array}{l}\text { Color: Dark Brown } \\
\text { Smell: Garlicky } \\
\text { Homogeneity }\end{array}$ & $18.968 \pm 0.039^{f}$ & 1.0574 & $5.96 \pm 0.02^{b}$ & 1.3438 \\
\hline $\mathrm{E} 3$ & $\begin{array}{l}\text { Color: Dark Brown } \\
\text { Smell: Garlicky Homogeneity }\end{array}$ & $22.214 \pm 0.11^{\mathrm{g}}$ & 1.0734 & $5.94 \pm 0.01^{\mathrm{b}}$ & 1.3560 \\
\hline
\end{tabular}

Different superindexes show a significant difference among samples ( $p<0.05)$, in total solid parameters and $p H$. 
TABLE IV - Values of the concentration of total phenols expressed as tannic acid for each one of the extracts

\begin{tabular}{|c|c|c|c|c|c|c|c|}
\hline $\begin{array}{l}\text { Extracts } \\
(\text { Mean } \pm \text { Standard error) }\end{array}$ & $\mathrm{B}_{5}$ & $\mathrm{~B}_{6}$ & $\mathrm{~B}_{7}$ & $\mathrm{~B}_{8}$ & $\mathrm{E}_{1}$ & $\mathrm{E}_{2}$ & $\mathrm{E}_{3}$ \\
\hline $\begin{array}{l}\text { Concentration of } \\
\text { Total Phenols }(\mathrm{mg} / \mathrm{mL}) \\
\text { Mean }\end{array}$ & $\begin{array}{c}0.1228 \pm \\
0.003^{\mathrm{a}}\end{array}$ & $\begin{array}{c}0.2356 \pm \\
0.003^{\mathrm{b}}\end{array}$ & $\begin{array}{c}0.2561 \pm \\
0.0007^{\mathrm{c}}\end{array}$ & $0.356 \pm 0.015^{\mathrm{g}}$ & $\begin{array}{c}0.1652 \pm \\
0.0001^{\mathrm{e}}\end{array}$ & $\begin{array}{c}0.2502 \pm \\
0.0008^{f}\end{array}$ & $\begin{array}{r}0.3583 \pm \\
0.0006^{\mathrm{g}}\end{array}$ \\
\hline
\end{tabular}

Different superindexes represent a significant difference between the samples $(\mathrm{p}<0.05)$

It can be verified that organoleptic characteristics of extracts show a dark brown color, a garlicky smell which is characteristic of the plant (Roig, 1988; MINSAP, 1993; National Pharmacy Bureau MINSAP, 2010) and homogeneity.

In the case of total solids, percentages obtained in blended extracts are greater than in soft extracts; so it can be suggested that this technique of extraction allows us to obtain a greater quantity of substances in each of the proportions obtained, with significant statistical differences among all the extracts for $95 \%$ confidentiality. (Table III). The Cochran test indicates the presence of homogeneity of variance since the $\mathrm{p}$ value is greater than 0.05 (Cochran's C Contrast: 0.424714, $\mathrm{P}$-value $=0.559725)$.

Relative density values obtained indicate they are higher in the case of blended extracts and that they increase as both types of extracts become more concentrated.

In the case of the $p H$, values indicate the presence of weak acid characteristics of the substances extracted from these extracts; such as flavonoids, phenols and tannins (National Pharmacy Bureau, MINSAP, 2010). The statistic analysis revealed that there is no significant statistical differences among each of the soft extracts and among each of the blended extracts for a $95 \%$ confidentiality; however, there are differences between both types of extracts, concerning weak acid characteristics of the substances extracted using both methods of extraction; with blended extracts showing greater acidity than soft extracts showing significant statistical differences for a $95 \%$ confidentiality (Table III). The Cochran test indicates the presence of homogeneity of variance, since the $p$ value is greater than 0.05 (Cochran's C Contrast: 0.216216, $\mathrm{P}$-value $=1,0)$.

The values of the refractive index, greater than the value of water at $20^{\circ} \mathrm{C}(1.333)$, indicate the presence of substances capable of refracting the light.

The results of the phytochemical screening indicate the possible presence of flavonoids in the seven extracts for the two tests performed. Also positive results were obtained for the test of phenols and tannins, saponins, quinones, triterpenes, steroids and alkaloids (National Pharmacy Bureau MINSAP, 2010).

Results from the determination of total phenols are shown below(Table IV):

Values obtained for $\mathrm{B}_{5-8}$ soft extracts range between 0.12 and $0.36 \mathrm{mg} / \mathrm{mL}$ approximately and between 0.16 and $0.36 \mathrm{mg} / \mathrm{mL}$ for $\mathrm{E}_{1-3}$ blended extracts, approximately (Table IV). It is observed that the concentration of total phenols increases as the concentration of both extracts rises; being the values of blended extracts higher with statistic differences for a $95 \%$ confidentiality.

The multiple range test, specifically the Tukey HSD Test, showed that the concentration of total phenols among all extracts is different, except for B8 soft extract and E3 blended extract. This last result shows how this blended extract, less concentrated than the soft one, obtains the same concentration of total phenols as E3 extract, showing that extraction using a blender, in this plant species, is more efficient than percolation.

Cochran test indicates that there is homogeneity of variance, since the $\mathrm{p}$ value is greater than 0.05 (Cochran's C Contrast: 0.529412, P-value $=0.0960229$ ).

The concentration of total phenols, even though is low, indicates the presence of chemical compounds with phenolic grouping, such as flavonoids, tannins and phenols (with positive results in the screening); it has been reported that they have antimicrobial action (Escalona, 2005; Ogunleye, Ibioteye, 2003), so it can be suggested that these metabolites can contribute, together with sulfur compounds (Seokwon, Roman, Rabi, 2006), to antimicrobial action in these extracts.

\section{CONCLUSIONS}

The antibacterial activity was obtained in B5, B6, B7, B8, B9, B10, E1, E2 and E3 extracts; showing the absence or low concentration of bioactive metabolites in those extracts that were negative: B1, B2, B3 and B4 extracts. 
Antifungal activity was not observed in any of the extracts evaluated.

$\mathrm{B} 8$ and $\mathrm{E} 3$, the most concentrated extracts, have the greatest spectrum of antibacterial action.

The highest antibacterial activity is achieved in E1, E2 and E3 blended extracts in the presence of P. aeruginosa.

The Inhibitory Minimum Concentration for B5, B6, B7, and B8 soft extracts is greater than $100 \mathrm{mg} / \mathrm{mL}$ and for blended extracts greater than $50 \mathrm{mg} / \mathrm{mL}$.

The Minimum Bactericidal Concentration for $\mathrm{B} 5, \mathrm{~B} 6, \mathrm{~B} 7$, and B8 soft extracts is greater or equal to $400 \mathrm{mg} / \mathrm{mL}$ and for blended extracts is greater or equal to $200 \mathrm{mg} / \mathrm{mL}$.

Blended extracts have greater percentage of total solids and greater concentration of total phenols.

Blended extracts are considered more active than soft extracts in the presence of the studied bacteria.

It is corroborated that the drying temperature influences the antimicrobial chemical composition of the Petiveria alliacea $\mathrm{L}$.

It is corroborated that the constituents responsible for the antimicrobial activity possess an apolar nature.

\section{REFERENCES}

BERDY, J.; HOSTIAN, M.; NITT, M.K. Hand book of antibiotic compounds. Boca Ratón: CRC Press, 1982. 361 p.

BENEVIDES, P.J.C.; YOUNG, M.C.M.; GIESBRECHT, A.M.; ROQUE, N.F.; BOLZANI, V.S. Antifungal polysulphides from Petiveria alliacea L. Phytochemistry, v.57, n.5, p.743747, 2001.

CÁCERES, A.; LÓPEZ, B.; GONZÁLEZ S. Plants used in Guatemala for the treatment of protozoal infections. I. Screening of activity to bacteria, fungi and American trypanosomes of 13 native plants. J. Ethnopharmacol., v.62, n.3, p.195-202, 1998.

CECMED. Guía metodológica para la investigación de plantas medicinales, dirección de ciencia y técnica. Área de docencia e investigación. La Habana, Abril, 1997: 8-24

CUBA. Buró nacional de farmacia MINSAP. Formulario nacional fitofármacos y apifármacos. Habana: Editorial Ciencias Medicas, 2010. p.15.

CUBA. Ministerio de salud pública (MINSAP). Plantas medicinales. FITOMED II. Habana: Editorial Ciencias Médicas, 1993. p.8.
CUBA. Norma ramal de salud pública (NRSP) 311. Extractos Fluidos y Tinturas. Procesos Tecnológicos. Habana: MINSAP, 1991. p.3.

CUBA. Norma ramal de salud pública (NRSP) 312. Extractos Fluidos y tinturas. métodos de ensayos. Habana: MINSAP, 1991. p.1-5.

ESCALONA, J.C. Estudio químico farmacéutico de las hojas del Tamarindus indica L. Valoración teórica de la actividad de los flavonoides. [Thesis paper to be awarded the Master's Degree in Traditional Medicine and Bioenergetics]. ISCM, Santiago de Cuba, 2005.

GUEDES, R.C.M.; NOGUEIRA, N.G.P.; FUSCO-ALMEIDA, A.M.; SOUZA, C.R.F.; OLIVEIRA, P.W. Atividade antimicrobiana de extratos brutos de Petiveria alliacea $\mathrm{L}$. Lat. Am. J. Pharm., v.28, n.4, p.520-524, 2009.

GONZÁLEZ, J.; LECHUGA, A.M.; SERRANO, C.A. Estudio fitoquímico comparativo de Oenothera rosea y Oenothera multicaules (Yawar Chonq'a). Rev. SITUA., v.9, n.17, p.66, 2000.

ILLNAIT, J.F. Principales referencias etnomédicas sobre el anamú. Rev. CENIC Cienc. Biol., v.38, n.1, p.27-30, 2007.

LAPENNA, E.A.; MEDINA, G.E.R.; DÍAZ, L.; AGUILLON, K.; MARÍN, H. Actividad bactericida y fungicida de algunas plantas utilizadas en la medicina tradicional Venezolana. Rev. Inst. Nac. High., v.34, n.1, p.20-30, 2003.

LEMUS, Z.R.; GARCÍA, M.E.P.; BATISTA, A.D.; DE LA GUARDIA, O.P.; ALFONSO, A.C. La tableta de anamú: un medicamento herbario inmunoestimulante. Medisan, v.8, n.3, p.57-64, 2004.

NATIONAL COMMITTEE FOR CLINICAL LABORATORY STANDARDS. Performance standards for antimicrobial susceptibility testing. XII informational supplement. M100-s12. Wayne: NCCLS, 2002. p.9-14.

OCHOA, A.P.; PUPO, M.P.; DUANY, K. Caracterización y estudio de estabilidad físico-química preliminar de las hojas de la especie Petiveria alliacea L. (anamú). Rev. Cub. Quím., v.12, n.3, p.68-76, 2000.

OCHOA, AP.; LÓPEZ, T.G.; COLOMBAT, M.R. Farmacognosia y química de los productos naturales. Version 1.0 for windows. Santiago de Cuba: Universidad de Oriente, c2002. CD-ROM. 
OCHOA, A.P.; GROSS, C.F.; ARMAS, A.C.; GUTIÉRREZ, Y.F. Anti-inflammatory activity of the soft extract and ointments of Petiveria alliacea L. in rats. Pharmacology online, v.3, p.683-689, 2006a.

OCHOA, A.P.; MARÍN, J.M.; FERNÁNDEZ, D.F.; VINET, Y.G.; GARCÍA, Y.R. Estandarización preliminar de parámetros de calidad del extracto blando de las hojas de Petiveria alliacea L. Rev. Cub. Quím., v.18, n.3, p.78-83, $2006 b$.

OCHOA, A.P.; MARÍN, J.M.; SILVA, R.P.; DELGADO, B.N.F.; SALGUEIRO, Z.B. Estudio Tecnológico del extracto blando de las hojas de Petiveria alliacea L. Rev. CENIC, Cienc. Quim., v.39, n.3, p.141-145, 2008 a.

OCHOA, A.P.; MARÍN, J.M.; SILVA, R.P.; DELGADO, B.N.F.; SALGUEIRO, Z.B. Estudio de Estabilidad física y química cualitativa del extracto blando optimizado de las hojas de la Petiveria alliacea L. Rev. Cub. Quím., v.20, n.1, p.3-8, 2008 b.

OGUNLEYE, D.S.; IBIOTEYE, S.F. Studies of antimicrobial activity and chemical constituents of Ximenia Americana. Trop. J. Pharm. Res., v.2, n.2, p.239-241, 2003.
REFERENCE LABORATORY. Inhibitory Minimum Concentration (IMC). Available at: <http://www. labreferencia.com/content.aspx? $\mathrm{id}=965>$. Accessed on: May 20, 2010.

ROIG, J. Plantas medicinales, aromáticas o venenosas de Cuba. 2.ed. Habana: Editorial Científico-Técnica, 1988. p.1580-1160.

SEOKWON, K.; ROMAN, K.; RABI, A.M. Antibacterial and antifungal activity of sulfur-containing compounds from Petiveria alliacea L. J. Ethnopharmacol., v.104, n.2, p.188192, 2006.

SINGLETON, V.L.; ROSSI, J.A. Colorimetry of total phenolics with phosphomolybdic-phosphotungstic acid reagents. $\mathrm{Am}$. J. Enol. Vitic., v.20, n.2, p.144-158, 1965.

Received for publication on $23^{\text {rd }}$ February, 2012 Accepted for publication on $16^{\text {th }}$ January, 2013 
ANNEX 1: Results of the Statistical Analysis in the antimicrobial evaluation in the presence of $P$. aeruginosa (B567-E123) and S. aureus (B_567-E_123).

Contrast of Hypothesis for B5-E1 P. aeruginosa Sample Mean $=-1.125$

Sample Median= -1.0

T-Contrast

Null Hypothesis: mean $=0.0$

Alternative: not equal

T-Statistic $=-9.0$

$\mathrm{P}$-value $=0.00289581$

The null hypothesis is rejected for alpha $=0.05$.

Contrast of Hypothesis for B6-E2 P. aeruginosa Sample Mean $=-5.83333$

Sample Median = -6.0

T Contrast

Null hypothesis: mean $=0.0$

Alternative: not equal

T-Statistic $=-35.0$

$\mathrm{P}$-value $=0.000815328$

The null hypothesis is rejected for alpha $=0.05$.

Contrast of the hypothesis for B7-E3 P. aeruginosa Sample Mean $=-5.66667$

Sample Median = -5.5

T Contrast

Null hypothesis: mean $=0.0$

Alternative: not equal

T Statistic $=-34.0$

$\mathrm{P}$-value $=0.000863931$

The null hypothesis is rejected for alpha $=0.05$.
Contrast of Hypothesis for B_5-E_1 S. aureus

Sample Mean $=-0.665$

Sample Median $=-0.58$

\section{T Contrast}

Null hypothesis: mean $=0.0$

Alternative: not equal

T Statistic $=-5.64215$

$\mathrm{P}$-value $=0.0110175$

The null hypothesis is rejected for alpha $=0.05$.

Contrast of Hypothesis for B_6-E_2 S. aureus

Sample Mean $=-1.00333$

Sample Median $=-1.0$

\section{T Contrast}

Null hypothesis: mean $=0.0$

Alternative: not equal

T Statistic $=-301.0$

$\mathrm{P}$-value $=0.0000110372$

The null hypothesis is rejected for alpha $=0.05$.

\section{Contrast of Hypothesis for B_7-E_3 S. aureus}

Sample Mean $=-1.335$

Sample Median $=-1.17$

\section{T Contrast}

Null hypothesis: mean $=0.0$

Alternative: not equal

T Statistic $=-5.66378$

$\mathrm{P}$-value $=0.0109003$

The null hypothesis is rejected for alpha $=0.05$.

This is a true translation of the original

EQUIPO DE SERVICIOS DE TRADUCTORES E INTÉRPRETES 